Serhiienko et al., 2022

Volume 7 Issue 3, pp. 112-125

Received: 01st September 2021

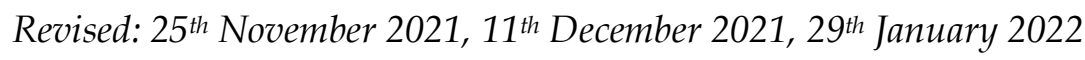

Accepted: 05 ${ }^{\text {th }}$ February 2022

Date of Publication: 07th February 2022

DOI- $h$ ttps://doi.org/10.20319/mijst.2022.73.112125

This paper can be cited as: Serhiienko, A. O., Dontsova, T. A. E Vorobyova, V. I. (2022). Synthesis of Bactericidal Microfiltration Ceramic Membranes. MATTER: International Journal of Science and Technology, 7 (3), 112-125.

This work is licensed under the CreativeCommons Attribution-NonCommercial 4.0 International License. To view a copy of this license, visit http://creativecommons.org/licenses/by-nc/4.0/ or send a letter to Creative Commons, PO Box 1866, Mountain View, CA 94042, USA.

\title{
SYNTHESIS OF BACTERICIDAL MICROFILTRATION CERAMIC MEMBRANES
}

\author{
Alla O. Serhiienko \\ Faculty of Chemical Technology, National Technical University of Ukraine "Igor Sikorsky Kyiv \\ Polytechnic Institute”, Kyiv, Ukraine \\ allasergienko706@gmail.com \\ Tetiana A. Dontsova \\ Faculty of Chemical Technology, National Technical University of Ukraine "Igor Sikorsky Kyiv \\ Polytechnic Institute”, Kyiv, Ukraine \\ dontsova@xtf.kpi.ua \\ Victoria I. Vorobyova \\ Faculty of Chemical Technology, National Technical University of Ukraine "Igor Sikorsky Kyiv \\ Polytechnic Institute”, Kyiv, Ukraine \\ vorobyovavika1988@gmail.com
}

\section{Abstract}

Membrane technologies have become widely used in filtration and separation processes in chemical, oil, food, pharmaceutical, medical, environmental, textile industries, etc. Recently, there is a growing demand for the use of bactericidal membranes due to their effectiveness in neutralizing microorganisms. The aim of this work is to synthesize microfiltration ceramic membranes modified with silver nanoparticles to provide them with bactericidal properties. In this 
work, ceramic membranes are synthesized by dry pressing followed by sintering from natural raw materials of Ukrainian origin, namely: kaolin and saponite, as well as with the addition of silicon carbide, sodium silicate, and calcium carbonate. To provide ceramic membranes with bactericidal properties, they were modified with particles of silver. The synthesized ceramic membranes were characterized by X-ray diffraction and fluorescence analysis, and their bactericidal ability has been established. The ceramic filtration membranes after modification by silvers exhibited an inhibitory effect on the growth of Gram-positive (B. subtilis.) and Gram-negative (Escherichia coli) pathogens. Thus, the obtained bactericidal ceramic membranes are of great interest for their use for biofouling control.

\section{Keywords}

Bactericidal Ceramic Membranes, Microfiltration, Silver, Water Treatment

\section{Introduction}

Water is the basis of all organic life, without which neither human existence nor the development of mankind as a whole is possible. Along with the problem of limited water resources, the issue of their quality is no less acute. Many countries are at risk of a water crisis. It is anticipated that the need for access to water resources shall increase in the coming years (Duzdaban, 2021). Water pollution is a serious problem for many countries and needs to be resolved as soon as possible (Aini Zakaria, Wan Mansor, \& Shahrin, 2018). Its solution requires the development of traditional methods and the creation of new methods and technologies. One of the most advanced methods of filtering water is its membrane purification.

Membrane technologies are a high-tech method of water purification and occupy a special place in the field of water treatment. This technology is used to filter water from mechanical and organic contaminants, bacteria and viruses, and in solution separation, water softening, wastewater treatment and production of sterile liquids. These processes find applications in chemical, oil, food, pharmaceutical, medical, environmental, textile industries, etc. Membrane filters are thin and have a fairly controlled pore size. Nowadays, the filter materials are usually polymers and ceramics.

Composite membranes have recently attracted attention as each layer can be independently modified to achieve the desired membrane characteristics (Hong Anh Ngo, \& Thi Tran, 2017). In particular, ceramic membranes remain one of the most promising technologies among membrane processes due to their superior performance, hydrophilicity, mechanical robustness, and high thermal and chemical stabilities. Ceramic membranes are characterized by reliability and long 
service life under routine conditions, as well as the possibility to restore the filtration properties by membrane regeneration, including backwashing. (Gitis \& Rothenberg, 2016, Serhiienko, Dontsova, Yanushevska, Nahirniak, \& Ahmad, 2020). Ceramic membranes are used for different types of filtration depending on the average pore size: ultrafiltration, microfiltration and nanofiltration. However, despite several advantages, ceramic membranes are not protected from biofouling. Even under correct operating conditions, it is inevitable that the membrane will become contaminated after prolonged operation. Membrane fouling is a serious problem in the application of a ceramic membrane, which is mainly caused by the deposition and adsorption of certain components in the filtrate at the membrane surface or in the pores of the membrane. Bacteria may also be growing in the pores of the membrane or on its surface, reducing the membrane's permeability and causing it to become contaminated Zuo, Zhang, Ma, Lv, \& Li, 2020). Therefore, the issue of the production of ceramic membranes endowed with bactericidal properties is of interest.

\section{Literature Review}

Many works have been devoted to the study of the performance of ceramic membranes. Various kinds of inorganic membrane materials are available on the market. The properties of ceramic membranes are basically defined by their composition, the choice of pore formers and the temperature of heat treatment. According to the literature, most often ceramic membranes are made of Al, Ti, Si, and Zr oxides (Samaei, Gato-Trinidad, \& Altaee, 2018). However, the production of membranes based on these materials requires high economic costs. To reduce costs, recent research has focused on the use of natural materials such as clays, natural zeolites, apatites, quartz sand, and others for the production of ceramic membranes (Abdullayev, Bekheet, Hanaor, \& Gurlo, 2019). Clays are widespread around the world and require minimal processing before use in the

production of ceramic membranes. Kaolin is the most common type of clay whose main mineral form consists of kaolinite. Kaolin-based ceramic membranes are characterized by mechanical stability and high porosity, which are achieved by heat treatment.

There are different methods for producing ceramic membranes from raw materials such as slip casting, pressing, extrusion, dip coating, sol-gel method, etc. The choice of any preparation method depends on the desired membrane structure and future use (Amin, Abdallah, Roushdy, \& El-Sherbiny, 2016). 
The traditional method of obtaining porous ceramic substrates is sintering powders with binders, which can be liquid glass, clay minerals (kaolinite, montmorillonite), aluminophosphate binder, organics and others. To increase the porosity of ceramics in some cases, burnout (sawdust, flour, starch) or gas-forming (calcite, megnesite) additives are introduced. By regulating the dispersion of powders, the amount and nature of binders, additives and the method of heat treatment of the mixture, a ceramic support with different porosity and permeability is obtained.

There are many research papers devoted to the study of membrane fouling control strategies. Membrane cleaning methods can be divided into physical methods (reversible fouling cleaning) and chemical methods (irreversible fouling cleaning). Physical methods are reagent-free methods of membrane cleaning, and include Hydraulic flushing, backwashing, backpulsing, air enhanced backflushing, use of ultrasound, use of electric field and others. Chemical cleaning of membranes is a so-called cleaning-in-place (CIP) using the following typical reagents: alkalis, oxidants/disinfectants, acids, chelating agents, surfactants and enzymes (Gruskevica \& Mezule, 2021).

Ways to prevent membrane fouling include water pretreatment, timely hydraulic and chemical flushing, reagent dosing, or special membrane design. One way to prevent the biological fouling of ceramic membranes is to modify the membranes with certain metal nanoparticles, such as $\mathrm{Ag}$ and $\mathrm{Cu}$, which are well-known for their antibacterial properties (Lu et al., 2016, Kim \& Van, 2010). Previous investigations have shown the use of silver particles to reduce membrane biofouling using various methods of membrane production. Basically, there are two main ways of adding Ag nanoparticles (Ag NPs) to the membrane surface, namely, making a membrane from a mixture that contains Ag NPs in advance and modifying an existing membrane by the coating method. There is evidence in the literature that Ag NPs not only provide disinfection but also reduce contamination by reducing biofilms on the membrane surface (Bolto \& Xie, 2018, Diagne et al., 2012, Le et al., 2019).

By incorporation of $\mathrm{Ag}$ nanoparticles (NPs) into the ceramic matrix, antibacterial properties can be added to the ceramic membranes. In (Ngoc Dung, Phan Thi, Nam, Nhan, \& Quang, 2019) a highly porous ceramic filter with silver particles incorporated into its structure, obtained by the in situ chemical reduction method, was fabricated. For this purpose, the $\mathrm{AgNO}_{3}$ was first impregnated with activated carbon with a further addition to the ceramic filter production 
mixture. In doing so, the silver particles are distributed evenly throughout the porous ceramic filter, allowing it to slowly release and maintain its antibacterial effectiveness for prolonged filtration.

In another research ( $\mathrm{Lv}$ et al., 2009) to fix silver nanoparticles in porous ceramic composites using as a binder aminosilane binding agent, namely 3- aminopropyltriethoxysilane. After passing inlet water with a bacterial load of $\sim 10^{5}$ colony-forming units (CFU) per milliliter through the silver-decorated porous ceramic at a flow rate of 0.01 1/min, no E. coli was detected in the output water.

In the paper (Singh, Rento, Son, Turner, \& Smith, 2019), ceramic tablets were made in different ways by changing the pressure in the mold, temperature and sintering rates, sawdust composition, mixing protocols of starting materials and granulation. The prepared ceramic samples were investigated for the release of silver ions into water for periods of 8 to 24 hours.

An alternative method of adding silver to ceramic filters before sintering is compared in the literature with the traditional methods of applying silver particles after heat treatment of the product (Jackson, \& Smith, 2018). The preparation of ceramic water filters by adding silver nitrate to the initial mixture of clay, sawdust and water can improve the retention of silver in the filter, support effective pathogen removal, reduce production costs, and minimize the risk of inhalation of silver nanoparticles by workers. Filters were evaluated using a series of mixing flow experiments using a non-pathogenic strain of E. coli and $\left[{ }^{3} \mathrm{H}\right] \mathrm{H}_{2} \mathrm{O}$.

Another major study (Mukaratirwa-Muchanyereyi et al., 2020) describes ceramic water purification filters made from clay, broken clay pots and flour, with the addition of silver nitrate in one case and silver nanoparticles in the other by immersing the formed discs in the respective solutions. The effectiveness in reducing the $\mathrm{pH}$ of the original water, water hardness, biological oxygen demand (BOD), chloride and nitrate concentrations after passing through the ceramic filters are compared. The paper (Kallman, Oyanedel-Craver, \& Smith, 2011) mentions ceramic filters prepared by mixing clay, sawdust and water, followed by impregnation with silver nanoparticles. The filters have been successfully tested for the transfer and removal of E. coli under laboratory and field conditions.

Recently, Ag NPs on ceramic materials has attracted considerable attention due to their disinfection and reduction of biofouling for household (point-of-use) water treatment (Shepard, Lux, \& Oyanedel-Craver, 2020). Ceramic filters containing sawdust and commercial clays and 
similar filters with added AgNPs were evaluated for flow rate, turbidity removal, bacteria removal and silver leaching.

The aim of this work is to synthesize bactericidal microfiltration ceramic membranes. For this purpose, ceramic membranes were modified with silver nanoparticles. The effect of silver content on the bactericidal properties of the membrane is described.

\section{Methodology}

Ceramic membrane supports were prepared by dry pressing followed by sintering. This method is suitable to produce flat round ceramic membranes for research of their properties. In general, ceramic membranes made by pressing have well-defined characteristics, such as uniform porosity and homogeneous physical properties over the entire membrane area and are widely used for fundamental research (Issaoui \& Limousy, 2019). This method is based on pressing dry powder using a press. To impart strength, the formed membrane is calcined at a temperature sufficient for sintering the initial substances.

To prepare sample CM0, the feedstock was ground and mixed in the following ratio: Kaolin $60 \%$, Saponite $10 \%$, Sodium silicate $10 \%$, Calcium carbonate $20 \% .2 \mathrm{~g}$ of the mixture of powders was weighed and then poured into the $2.2 \mathrm{~cm}$ diameter press mould. Round ceramic membrane supports were made by hand hydraulic pressing at 8 tons of pressure. Heat treatment was performed in the air in a high-temperature muffle furnace at a heating rate of $1{ }^{\circ} \mathrm{C} / \mathrm{min}$ to $95{ }^{\circ} \mathrm{C}$ with isothermal holding for $30 \mathrm{~min}$, at a rate of $3{ }^{\circ} \mathrm{C}$ per min to $350{ }^{\circ} \mathrm{C}$ and at a rate of $2{ }^{\circ} \mathrm{C}$ per min up to $950{ }^{\circ} \mathrm{C}$, followed by holding at this temperature for 60 minutes. Finally, the samples spontaneously cooled to room temperature.

Samples of bactericidal ceramic membranes modified with silver were prepared similarly, only at the stage of mixing the starting materials was added silver nitrate in terms of $\mathrm{Ag}$ in the following contents: $0.5 \%, 1 \%, 2 \%, 4 \%$ and $5 \%$.

X-ray diffraction analysis was performed using a Rigaku Ultima IV X-ray diffractometer (Japan) with CuKa radiation. The size of the crystallites was calculated using Scherer's formula.

The chemical composition was determined using an EXPERT 3L INAM X-ray fluorescence analyzer (Ukraine).

Test strains, such as Gram-negative bacteria Escherichia coli UKM B-906 and Grampositive (B. subtilis) were obtained from Danylo Zabolotny Institute of Microbiology and Virology 
of the National Academy of Science of Ukraine. Before testing inoculums were cultivated in liquid medium meat-and-peptone broth for 6 hours at $370{ }^{\circ} \mathrm{C}$. The inoculum suspension was diluted to an optical density of 0.5 according to the McFarland standard scale, which corresponds to $10^{8}$ colony-forming units $\left(\mathrm{CFU} / \mathrm{cm}^{3}\right)$. The test was conducted by the diffusion method on a solid medium which is based on ceramic filtration membranes in nutrient agar and inhibition of bacteria growth. The inoculum was densely touched by swab on sterile agar in Petri dishes, after that the pieces of catgut threads were placed on the surface. Petri dishes were incubated at $37{ }^{\circ} \mathrm{C}$ for 24 hours. Evaluation of antibacterial activity was provided by measuring of size of the inhibition zones around the threads.

\section{Analysis}

The ceramic membrane CM0 and its initial components, namely Kaolin, Saponite, and Calcium Carbonate, were characterized by X-ray diffraction and fluorescence analysis. The bactericidal properties of ceramic membrane samples with and without silver modification were examined using the inhibition zone test.

\subsection{XRD}

Fig. 1 shows diffraction patterns for the components of ceramic membranes (Kaolin, Saponite, Calcium carbonate) and CM0 sample of a ceramic membrane made from them. X-ray diffraction analysis was performed using a Rigaku Ultima IV X-ray diffractometer (Japan) with CuKa radiation. According to standard cards (ICDD 01-078-2110 (Kaolinite), ICDD 01-087-2096 (Quartz), ICDD 01-083-0578 (Calcite), ICDD 01-073-2337 (Magnesium aluminosilicate) the components of ceramic membranes contain phases characteristic of them (Table 1), and CM0 ceramic membrane contains Magnesium aluminosilicate (Saponite). Thus, it can be concluded that as a result of the preparation and subsequent heating of the ceramic membrane, kaolinite is converted into metakaolin, which has an amorphous structure, and therefore, the diffraction pattern of the CM0 sample exhibits peaks characteristic only of the layered structure of saponite. Calcium carbonate decomposes to Calcium oxide, which also has an amorphous structure. 


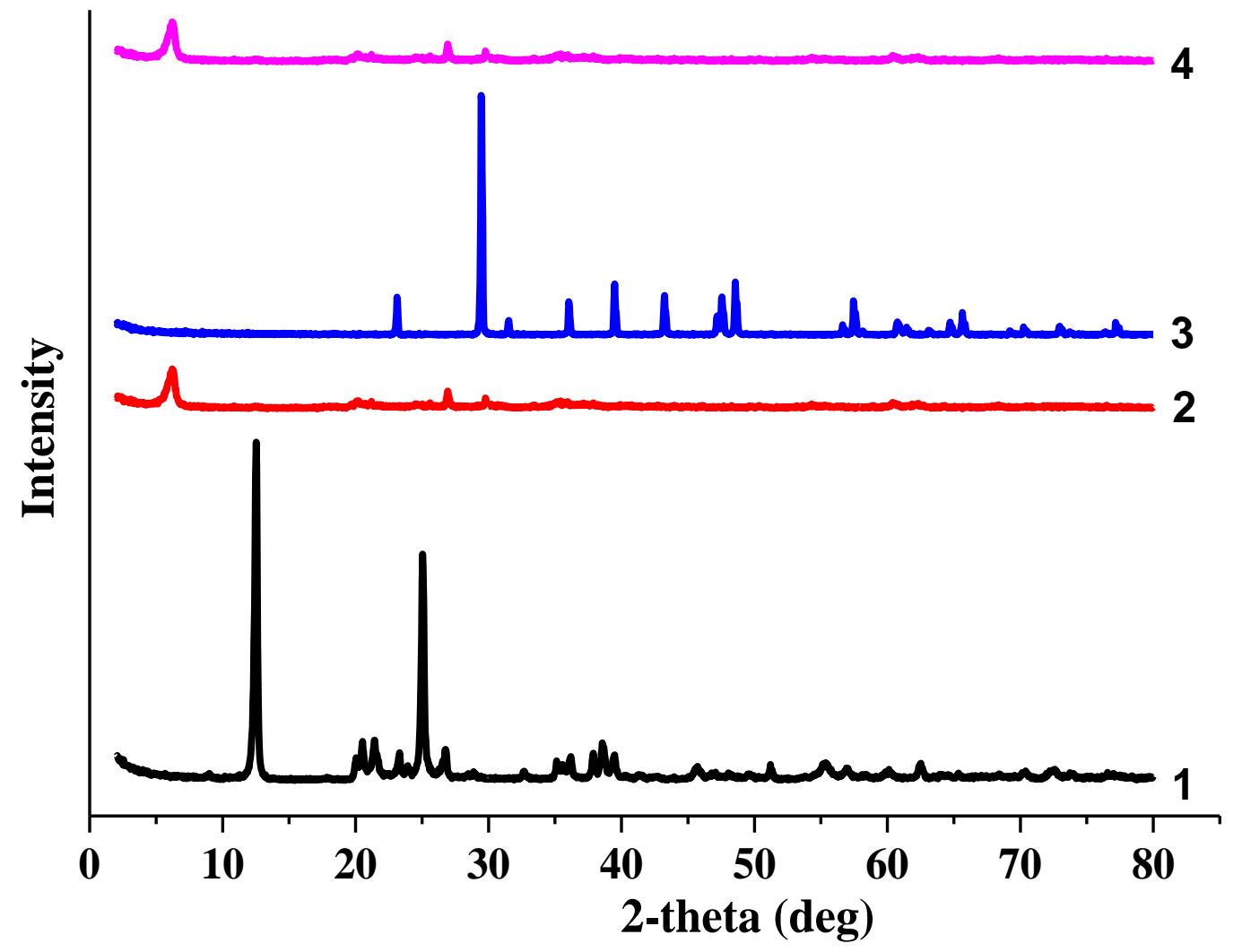

Figure 1: XRD Patterns of Samples: 1 -Kaolin; 2 - Saponite; 3 - Calcium Carbonate; 4 - CMO

(Source: Self)

The presented crystallite size in Table 1 indicates the nanocrystalline state of both the initial components and ceramic membrane (matrix).

Table 1: Composition and Crystallite Size of Samples

\begin{tabular}{|c|c|c|}
\hline Sample & Composition & Crystallite size, nm \\
\hline Kaolin & Kaolinite & 23 \\
\hline Saponite & Magnesium aluminosilicate (Saponite), Quartz & 13 \\
\hline Calcium carbonate & Calcium carbonate & 58 \\
\hline CM0 & Magnesium aluminosilicate (Saponite) & 18 \\
\hline
\end{tabular}

(Source: Self)

\subsection{Chemical composition}

Chemical analysis was used to determine the elemental composition of the samples. The samples were loaded in the EXPERT 3L INAM X-ray fluorescence analyzer (Ukraine) for elemental analysis. The chemical analysis is presented in Table 2. The chemical analysis of the samples revealed the main chemical elements inherent in the purposeful phases. 
Table 2: Chemical Analysis of Samples

\begin{tabular}{|c|c|c|c|c|}
\hline \multirow{2}{*}{ Element } & \multicolumn{4}{|c|}{ Composition, \% } \\
\hline & Kaolin & Saponite & Calcium carbonate & CMO \\
\hline $\mathrm{Si}$ & $\mathbf{5 7 . 7 5}$ & 36.15 & 0.22 & 17.98 \\
\hline $\mathrm{Al}$ & 32.34 & - & - & - \\
\hline $\mathrm{Ti}$ & 3.95 & - & - & - \\
\hline $\mathrm{K}$ & 2.57 & - & - & - \\
\hline $\mathrm{Fe}$ & 1.97 & 40.15 & 0.03 & 6.04 \\
\hline $\mathrm{Al}$ & - & 7.63 & - & 10.46 \\
\hline $\mathrm{Ca}$ & 0.89 & 6.80 & 99.28 & 63.06 \\
\hline $\mathrm{Mg}$ & - & 5.19 & - & - \\
\hline $\mathrm{S}$ & 0.30 & - & - & - \\
\hline $\mathrm{Ti}$ & - & 2.85 & 0.22 & 2.14 \\
\hline $\mathrm{Ga}$ & 0.03 & - & - & 0.02 \\
\hline $\mathrm{Zr}$ & 0.02 & 0.04 & - & 0.03 \\
\hline $\mathrm{Mn}$ & - & 0.59 & - & 0.07 \\
\hline V & 0.15 & 0.17 & 0.09 & 0.11 \\
\hline $\operatorname{Re}$ & 0.01 & - & - & - \\
\hline $\mathrm{Ni}$ & 0.01 & 0.09 & - & - \\
\hline $\mathrm{Cu}$ & 0.01 & 0.13 & - & 0.02 \\
\hline $\mathrm{Zn}$ & - & 0.10 & 0.01 & 0.01 \\
\hline $\mathrm{Cr}$ & - & 0.04 & - & - \\
\hline $\mathrm{Sr}$ & - & 0.03 & 0.13 & 0.04 \\
\hline $\mathrm{Rb}$ & - & 0.02 & 0.01 & 0.01 \\
\hline$Y$ & - & 0.02 & 0.01 & 0.01 \\
\hline
\end{tabular}

(Source: Self)

\subsection{Bactericidal ability}

The bactericidal ability of ceramic membranes was investigated according to the method described in the "Methodology" section. The size of the zone of inhibition clearly shows the efficiency of modified ceramic membranes as shown in Fig. 2 and Fig. 3. 

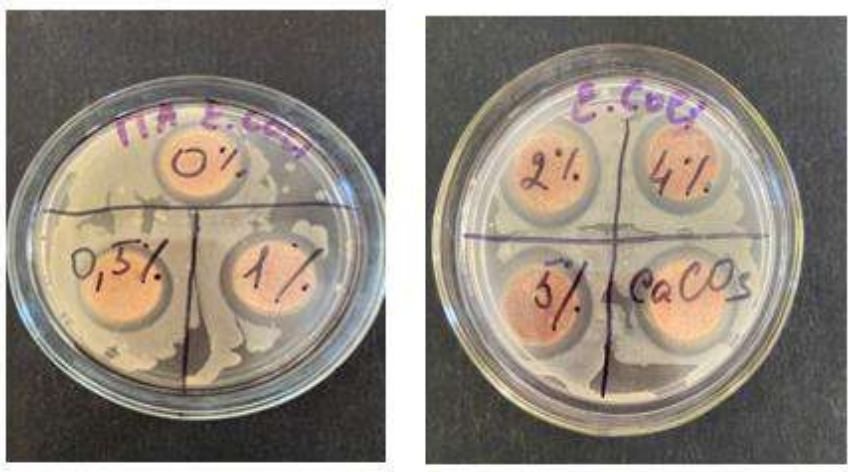

$24 \mathrm{~h}$
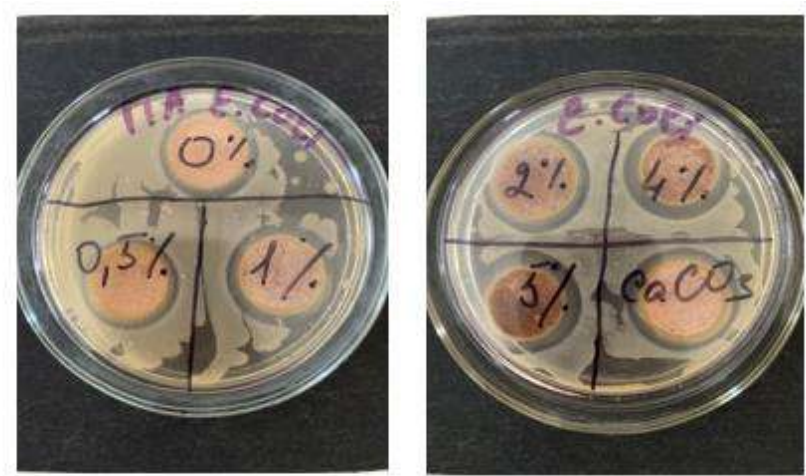

$48 \mathrm{~h}$

Figure 2: Inhibition Zone of Functionalization Ceramic Filtration Membranes against $E$. coli after Incubation for 24 And $48 \mathrm{H}$

(Source: Self)

As a general result, it was observed that the modified ceramic membranes showed higher activity against $B$. subtilis compared with $E$. coli. The inhibitory effect of ceramic membranes on the growth of bacteria were observed after incubation at $37^{\circ} \mathrm{C}$ for 24 and $48 \mathrm{~h}$. Further, it was noticed that uncoated membranes have a slight influence on the removal of the bacteria under study.

To study the effect of silver concentration, its content was varied from 0.5 to $5 \%$ against both strains of bacteria. The inhibitory activity of bactericidal ceramic membranes with increased silver concentration was increased. It is noticed that $\mathrm{Ag}$ is evenly covered on the membrane surface. At the same time, a small amount of $0.5 \%$ showed a significant effect on the removal of B. subtilis and E. coli. The radius of inhibition is uniformly uniform. Additional control on the second day and after one week of cultivation did not demonstrate any difference.

These results showed that the antibacterial properties presented by functionalized ceramic filtration membranes can be ascribed to the presence of silver over their large surface area that ensures greater surface contact with microorganisms. Antimicrobial activity depends mainly on the release of silver ions from the surface of bactericidal ceramic membranes. 

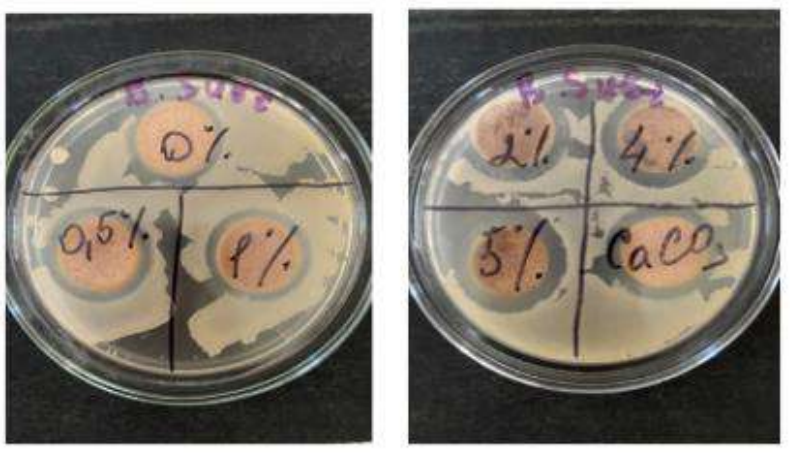

$24 \mathrm{~h}$
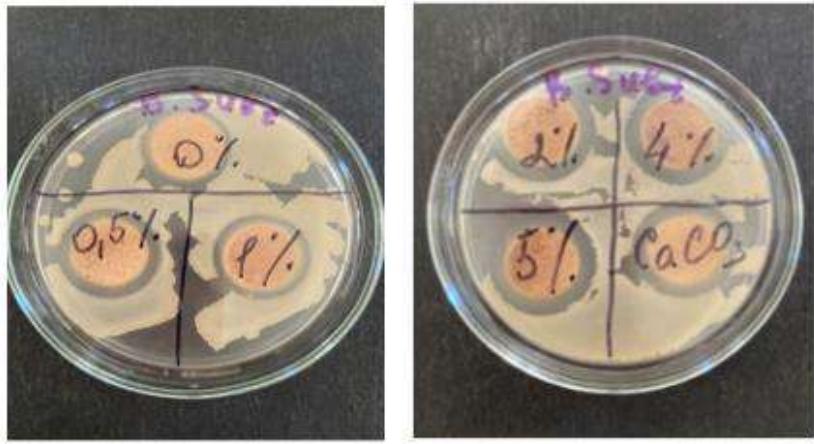

$48 \mathrm{~h}$

Figure 3: Inhibition Zone of Functionalization Ceramic Filtration Membranes against B. Subtilis after Incubation For 24 And $48 \mathrm{H}$

(Source: Self)

\section{Conclusion}

The raw components and obtaining ceramic membranes were characterized by X-ray methods, as a result of which the transformation of kaolin and calcium carbonate into metakaolin and calcium oxide was observed. The saponite phase does not undergo any changes during heating.

The antimicrobial properties of silver-modified ceramic membranes were investigated. The test of the zone of inhibition established an increased antimicrobial efficiency of the material, APMB, against the two bacteria (Gram-negative Escherichia coli and Gram-positive Bacillus subtilis) and the level for both bacteria showed dose-dependent antibacterial activity. The results indicate that the silver content in the amount of $0.5 \%$ exhibits high antibacterial activity against B. subtilis and E. Coli. To confirm the results obtained, more experimental studies need to be carried out. In the future, it is planned to study the mechanical and transport characteristics of obtaining ceramic membranes.

\section{Acknowledgments}

We thank the National Research Foundation of Ukraine for "Support for research by leading and young scientists", within the framework of which the work was carried out (project registration number 2020.02/0024). 


\section{REFERENCES}

Abdullayev, A., Bekheet, M., Hanaor, D., \& Gurlo, A. (2019). Materials and applications for low-cost ceramic membranes. Membranes, 9(9), 105. https://doi.org/10.3390/membranes9090105

Aini Zakaria, H., Wan Mansor, W. S., \& Shahrin, N. (2018). Development of water treatment sachets from the seeds of moringa oleifera and activated carbon. MATTER: International Journal of Science and Technology, 3(3), 240-252. https://doi.org/10.20319/mijst.2018.33.240252

Amin, S. K., Abdallah, H. A. M., Roushdy, M. H., \& El-Sherbiny, S. A. (2016) An overview of production and development of ceramic membranes. International Journal of Applied Engineering Research, 11, 7708-7721.

Bolto, B. A., \& Xie, Z. (2018) Recent Developments in Fouling Minimization of Membranes Modified with Silver Nanoparticles. Journal of Membrane Science and Research, 4, 111120. https://doi.org/10.22079/JMSR.2018.79056.1168

Diagne, F., Malaisamy, R., Boddie, V., Holbrook, R. D., Eribo, B., \& Jones, K. L. (2012). Polyelectrolyte and SILVER Nanoparticle modification of microfiltration membranes to mitigate organic and bacterial fouling. Environmental Science \& Technology, 46(7), 4025-4033. https://doi.org/10.1021/es203945v

Duzdaban, E. (2021). Water issue in central Asia: challenges and opportunities. Eurasian Research Journal, 3(1), 45-62.

Gitis, V., \& Rothenberg, G. (2016). Ceramic membranes new opportunities and practical applications. Wiley-VCH Verlag GmbH \& Co. KGaA. https://doi.org/10.1002/9783527696550

Gruskevica, K., \& Mezule, L. (2021). Cleaning methods for ceramic ultrafiltration membranes affected by organic fouling. Membranes, 11(2), 131. https://doi.org/10.3390/membranes11020131

Hong Anh Ngo, T., \& Thi Tran, D. (2017). Removal of heavy metal ions in water using modified polyamide thin-film composite membranes. MATTER: International Journal of Science and Technology, 3(1), 91-103. https://doi.org/10.20319/mijst.2017.31.91103 
Issaoui, M., \& Limousy, L. (2019). Low-cost ceramic membranes: Synthesis, classifications, and applications. Comptes Rendus Chimie, 22(2-3), 175-187. https://doi.org/10.1016/j.crci.2018.09.014

Jackson, K. N., \& Smith, J. A. (2018). A new method for the deposition of metallic silver on porous ceramic water filters. Journal of Nanotechnology, 2018, 1-9. https://doi.org/10.1155/2018/2573015

Kallman, E. N., Oyanedel-Craver, V. A., \& Smith, J. A. (2011). Ceramic filters impregnated with silver nanoparticles for point-of-use water treatment in rural Guatemala. Journal of Environmental Engineering, 137(6), 407-415. https://doi.org/10.1061/(asce)ee.1943$\underline{7870.0000330}$

Kim, J., \& Van der Bruggen, B. (2010). The use of nanoparticles in polymeric and ceramic membrane structures: Review of manufacturing procedures and performance improvement for water treatment. Environmental Pollution, 158(7), 2335-2349. https://doi.org/10.1016/j.envpol.2010.03.024

Le, Sowe, Chen, Duong, Ray, \& Nguyen. (2019). Exploring Nanosilver-Coated Hollow Fiber Microfiltration to Mitigate Biofouling for High Loading Membrane Bioreactor. Molecules, 24(12), 2345. https://doi.org/10.3390/molecules24122345

Lu, H., Wang, J., Stoller, M., Wang, T., Bao, Y., \& Hao, H. (2016). An overview of nanomaterials for water and wastewater treatment. Advances in Materials Science and Engineering, 2016, 1-10. https://doi.org/10.1155/2016/4964828

Lv, Y., Liu, H., Wang, Z., Liu, S., Hao, L., Sang, Y., Liu, D., Wang, J., \& Boughton, R. I. (2009). Silver nanoparticle-decorated porous ceramic composite for water treatment. Journal of Membrane Science, 331(1-2), 50-56. https://doi.org/10.1016/j.memsci.2009.01.007

Mukaratirwa-Muchanyereyi, N., Tigere, W., Hokonya, N., Gusha, C., Guyo, U., \& Nyoni, S. (2020). Preparation and performance characterization of ceramic/silver nanoparticle composite in water purification. International Journal of Applied Ceramic Technology, 17(3), 1522-1530. https://doi.org/10.1111/ijac.13440

Ngoc Dung, T. T., Phan Thi, L.-A., Nam, V. N., Nhan, T. T., \& Quang, D. V. (2019). Preparation of silver nanoparticle-containing ceramic filter by in-situ reduction and 
application for water disinfection. Journal of Environmental Chemical Engineering, 7(3), 103176. https://doi.org/10.1016/j.jece.2019.103176

Samaei, S. M., Gato-Trinidad, S., \& Altaee, A. (2018). The application of pressure-driven ceramic membrane technology for the treatment of Industrial Wastewaters - A Review. Separation and Purification Technology, 200, 198-220. https://doi.org/10.1016/j.seppur.2018.02.041

Serhiienko, A. O., Dontsova, T. A., Yanushevska, O. I., Nahirniak, S. V., \& Ahmad, H.-B. (2020). Ceramic membranes: New trends and prospects (short review). Water and water purification technologies. Scientific and technical news, 27(2), 4-31. https://doi.org/10.20535/2218-93002722020208817

Shepard, Z. J., Lux, E. M., \& Oyanedel-Craver, V. A. (2020). Performance of silver nanoparticle-impregnated ovoid ceramic water filters. Environmental Science: Nano, 7(6), 1772-1780. https://doi.org/10.1039/D0EN00115E

Singh, R., Rento, C., Son, V., Turner, S., \& Smith, J. A. (2019). Optimization of silver ion release from silver-ceramic porous media for household level water purification. Water, 11(4), 816. https://doi.org/10.3390/w11040816

Zuo, X., Zhang, S., Ma, G., Lv, Y., \& Li, P. (2020). Analysis of ceramic membrane fouling behavior and cleaning technology. E3S Web of Conferences, 194, 04048. https://doi.org/10.1051/e3sconf/202019404048 